\begin{tabular}{|l|l|l||}
\hline \multicolumn{2}{|c|}{ PublisherInfo } \\
\hline \hline PublisherName & $:$ & BioMed Central \\
\hline \hline PublisherLocation & $:$ & London \\
\hline \hline PublisherImprintName & $:$ & BioMed Central \\
\hline \hline
\end{tabular}

\title{
Inflammation in ischaemic heart disease
}

\begin{tabular}{|l|l|l||}
\hline \multicolumn{2}{|c||}{ ArticleInfo } \\
\hline \hline ArticleID & $:$ & 4101 \\
\hline \hline ArticleDOI & $:$ & $10.1186 /$ ccf-1999-1941 \\
\hline \hline ArticleCitationID & $:$ & 1941 \\
\hline \hline ArticleSequenceNumber & $:$ & 38 \\
\hline \hline ArticleCategory & $:$ & Paper Report \\
\hline \hline ArticleFirstPage & $:$ & 1 \\
\hline \hline ArticleLastPage & $:$ & 2 \\
\hline \hline & & RegistrationDate : 1999-4-10 \\
\hline ArticleHistory & $:$ & OnlineDate \\
\hline \hline ArticleCopyright & $:$ & Current Science Ltd1999-4-10 \\
\hline \hline ArticleGrants & $:$ & \\
\hline \hline ArticleContext & $:$ & 130541111 \\
\hline \hline
\end{tabular}




\section{Keywords}

Myocardial infarction, ischaemia, infection

\section{Comments}

This review looks at the current knowledge of inflammation in myocardial ischaemia. The question is raised as to whether the characteristic features of inflammation seen after myocardial ischaemia are secondary to tissue damage, or whether the inflammatory changes and influx of polymorphonuclear lymphocytes (PMNs) are responsible for tissue injury beyond that caused by ischaemia alone. Although not of direct relevance to those working in the ICU environment this review makes interesting reading for anyone involved in acute medicine. Firstly the authors examine the fact that inflammation plays a role in atherogenesis. Animals fed a high cholesterol diet develop endothelial dysfunction early in the course of atherosclerosis, which leads to macrophage adhesion to the vessel wall, cytokine release, leukocyte deposition, infiltration and activation. Additionally, inflammation adds to reperfusion injury following thrombosis. The role of inflammation in precipitation of acute myocardial ischaemia is also examined. The platelet PMN- interaction may be important as PMNs synthesise nitric oxide (NO), reducing platelet aggregation, but, equally, PMN activation in turn activates platelets. Markers of inflammation have also been examined and the initial leukocyte count has been shown to be a marker of clinical severity of ischaemic events in myocardial infarction. Similar results have been found with other chemotactic markers. The clinical relevance of this information is that, if the inflammatory process can be modulated, then the outcome in acute ischaemic syndromes may be improved. Some evidence to support this theory is presented.

Overall the review is well structured and well written. It suggests a novel approach to ischaemic heart disease that may improve the outcome in the future.

\section{References}

1. Mehta JL, Li DY: Inflammation in ischaemic heart disease: Response to tissue injury or a pathogenic villain?. Cardiovasc Res. 1999, 43: 291-99.

This PDF file was created after publication. 